\title{
Impact of some new generation insecticides on soil arthropods in rice maize cropping system
}

\author{
Abhijit Ghosal ${ }^{1 *}$ (D) and Anusweta Hati
}

\begin{abstract}
Background: Soil is the backbone of agriculture, and soil arthropods and earthworms are one of the key factors for maintaining soil physical characters. Densities of these populations are also an indicator of soil fertility. Several insecticides are now applied in field to manage different borer insects and get deposited in soil. They may exert impact on the inhabitants of soil.
\end{abstract}

Methods: Seven different insecticides chemistry were evaluated to find out the impact (if any) on soil arthropods and earthworms in field condition. Simultaneously, richness of soil arthropods was enumerated using pitfall trap.

Result: The arthropod diversity present in the experimental site has $92.58 \%$ richness of class insecta population; of which the order hymenoptera accounts for $57.34 \%$. Other than class insecta, representatives of class arachnida, diplopoda, chilopoda, annelida, and crustacea are also recorded. Rynaxypyr, cartap hydrochloride, fipronil, and chlorpyrifos showed no significant detrimental effect on the collembola population present in soil. Then, 27.65\% and $13.47 \%$ reduction of collembola population was noted in the case of carbofuran- and phorate-treated plot. Several minute soil arthropods recorded during experiment includes minute ants, beetles, and soil oribatid mites pseudoscorpions. No appreciable toxic effect was noticed by the insecticides on the basis of mean population count over control. Carbofuran recorded the highest population of earthcasts ( $15.59 \%$ more over untreated check), while imidacloprid, chlorpyrifos, and phorate showed negative impact. Imidacloprid showed maximum toxicity toward the redworm. Further, 33.14\% reduction of population was recorded by imidacloprid and chlorpyrifos which also showed toxicity toward Eisenia fetida L, while rynaxypyr and fipronil recorded more population over control. Cartap hydrochloride, carbofuran, and phorate did not pronounce toxic impact on redworm.

Conclusion: Collembola population was less sensitive toward rynaxypyr, cartap hydrochloride, fipronil, and chlorpyrifos. Imidacloprid, chlorpyrifos, and phorate showed negative impact on earthworm.

Keywords: Arthropod, Collembola, Earthworm, Insecticides

\section{Background}

Arthropods that live in the soil perform a number of critical soil functions. Soil is made mostly of the feces of arthropods. Microbe-grazing by arthropods mineralizes nutrients to complete the nutrient recycling process. An array of arthropods, annelids, and enchytraeids is present in soil. Rigorous analysis may help to identify ecological mechanisms underlying the dynamics of pest insect population in

\footnotetext{
* Correspondence: ghosalabhijit87@gmail.com

${ }^{1}$ Sasya Shyamala Farm Science Centre, Ramakrishna Mission Vivekananda Educational and Research Institute (RKMVERI), Sonarpur, Kolkata, West Bengal 700150, India

Full list of author information is available at the end of the article
}

an agro-ecological system rendering less adverse impact (Allwood, 1996). Collembola are the most abundant soil arthropods and play an important role in decomposer food webs (Butcher, Snider, \& Snider, 1971; Petersen, 2002; Peterson \& Luxton, 1982). Earthworms which are aptly named as the intestines of earth contribute a huge deal in maintaining the soil health, principally through their activities in consuming organic matters fragmenting it and mixing it intimately with mineral particles to form aggregates. During their feeding, earthworms promote microbial activity greatly which in turn also accelerates the breakdown of organic matter. However, very little information is available 
about the eco-toxicological effects of pesticides on soil fauna. After the introduction of green revolution and high yielding varieties, use of commercial inputs and agrochemicals in agriculture was increased a thousand times. But due to indiscriminate use of agrochemicals, it reduces the fertility of the soil as soil is the repository of all types of chemical inputs including insecticides applied to combat insect pests of crop (Bhuyan, Sreedharan, Adhya, \& Sethunathan, 1993; El-Shahaat, Othman, El-Halfawy, \& Marei, 1987; Rache \& Coats, 1988). Insecticides are used in agricultural fields to maximize crop production; they are credited for increasing food production and helping to protect against crop loss caused by insect diseases. Despite their importance, insecticides also have negative impact, like toxic residues in food, water, air and soil, resurgence and resistance of insect pests, and effects on non-target organisms. The hazards of insecticides in soil largely depend on their persistence. The longer they persist, the greater are the chances for affecting the fauna present and contamination of environment which ultimately lead to distortion of soil health. When insecticides are sprayed or applied, an ample amount of the insecticide and their degraded products get mixed or accumulated into the top 10-15 cm layer of soil, the region of greatest activity of microorganisms and soil fauna (Blasco \& Pico, 2009; Das \& Mukherjee, 2000) and consequently, set the stage of interactions between insecticides and fauna in soil ecosystem. Disturbances caused by pollutants in the soil result in both qualitative and quantitative changes in fauna, which affect soil functioning (Cortet et al., 1999). Soil microarthropods are often used as bioindicators of agricultural soil quality (Cortet, Poinsot-Balaguer, Gillon, Joffre, \& Ourcival, 2002). Most studies of insecticides effects on soil communities have focused on earthworm and Collembola and few on soil living mites (Al-Assiuty, Bayoumi, Khalil, \& Van Straalen, 1993). Since pesticides are not $100 \%$ specific, they cause lethal and sublethal effects within non-target species (Adamski, Błoszyk, Bruin, \& Ziemnicki, 2007), and their lethality may show stage-dependence (Charmillot, Pasquier, Zufferey, \& Bovard, 2001). Biodiversity inventories need to be designed around the use of effective sampling and estimation procedures especially for hyperdiversive groups of terrestrial organisms such as arthropod community (Colwell \& Coddington, 1994). Studies of ecological communities require ideally that individuals in a sample be properly identifies and counted (Gotelli, 2004). However, this is not always possible, so that during identification, individuals are usually separated by morphotypes, treated as equivalent to species in species richness estimations (McGill et al., 2007). Therefore, it is important to understand and predict how agrochemicals, especially insecticides, may affect soil fertility through their effects on microorganisms responsible for maintaining soil fertility and the populations of invertebrates responsible for the recycling and translocation of nutrients and maintain the ecological niches.

\section{Materials and methods}

Experiment was conducted in the Instructional Farm of Sasya Shyamala Krishi Vigyan Kendra (Farm Science Centre) situated at Arapanch, Sonarpur, West Bengal, located at $22.4^{\circ} \mathrm{N}$ latitude, $88.2^{\circ} \mathrm{E}$ longitude during spring summer season of 2014 and 2015 in rice maize cropping system. Maize (cultivar P-740) seeds were sowed in plots measuring $3 \mathrm{~m} \times 3 \mathrm{~m}$ at a spacing of $50 \mathrm{~cm}$ between rows and $25 \mathrm{~cm}$ between plant to plant. Farm Yard Manure at 5 tons/ha and all the recommended dose of fertilizers N:P:K were applied as basal. No fertilizer and plant protection chemicals other than treatment schedule were applied during the crop growth period. Further, the insecticides under evaluation viz. rynaxypyr 0.4 Granules (G) at 4 kilogram $(\mathrm{kg}) /$ acre, fipronil $0.3 \mathrm{G}$ at $5 \mathrm{~kg} /$ acre, cartap hydrochloride $4 \mathrm{G}$ at $6 \mathrm{~kg} /$ acre, carbofuran $3 \mathrm{G}$ at $7.2 \mathrm{~kg} / \mathrm{acre}$, phorate $10 \mathrm{G}$ at $5 \mathrm{~kg} / \mathrm{acre}$, imidacloprid $0.5 \mathrm{G}$ at $23 \mathrm{~kg} /$ acre (sample provided by Bayer Crop Science Pvt. Ltd.), and chlorpyrifos 35 emulsifiable concentrate (EC) at 5 milliliter (ml)/liter (lt) (soil drenching) (selection of dose of the selected insecticides were based on the reports of Ghosal, Hati, Mal, Mukherjee, \& Mukherjee, 2018; Sarao \& Kaur, 2014; Karam, 2011) were applied at recommended dose in soil by mixing with fine sand during 45 days after sowing. To study on the arthropod abundance in the experimental site, pitfall traps $[15$ centimeter $(\mathrm{cm})$ height $\times 10 \mathrm{~cm}$ in diameter] (Melbourne, 1999) were adopted in each plots in south (Santos \& Cabanas, 2007). The traps were used empty and observation was taken twice in a day (07:00 to 19:00 and 19:00 to 7:00) (Goncalves \& Pereira, 2012). Then, 0.5 metre $^{2}\left(\mathrm{~m}^{2}\right)$ area from each plot were selected randomly and numbers of earth cast (represents the earthworm richness) present in the selected area were recorded by visual observation in successive observation on pretreatment, 15, 30, and 75 days after application of insecticides. Collected samples were preserved in $70 \%$ alcohol for further investigation.

The diversity indexes of Shannon $\left(\mathrm{H}^{\prime}\right)$ and Simpson diversity index (1-D), as well as the evenness index of Pielou (J), were used to assess insect diversity within.

$$
\begin{aligned}
&\left(\mathrm{H}^{\prime}=-\sum_{i=1}^{s} \frac{n i}{N} \times \ln \frac{n i}{N}\right), \quad(D\left.=\sum_{i=1}^{s} \frac{n i(n i-1)}{N(N-1)}\right), \\
&\left(J=\frac{\mathrm{H}^{\prime}}{\ln S}\right)
\end{aligned}
$$

In accordance with Magurran (2004), the unequal distribution of abundance between species allowed the use of the dominance index of Berger-Parker (1/d) to express the proportion of individuals accounted for by the 
most abundant species in each site. The species richness index of Margalef (DMg) was used to highlight the most species-rich site. In these formulae, ni is the number of individuals of each of the $i$ species in the sample, $N$ is the total number of individuals in the assemblage, $S$ is the number of species in the assemblage, $N \max$ is the number of individuals in the numerically dominant species in each locality, and $\ln$ is the natural logarithm. All these indices are commonly used in ecological community studies (Magurran, 2004).

$$
\left(1 / \mathrm{d}=\frac{1}{N \max / N}\right),\left(\mathrm{DMg}=\frac{S-1}{\ln \mathrm{N}}\right)
$$

To assay the microarthropods, soil samples were collected in polyethylene bags at an intervals of $0,15,30$, and 75 days after application of insecticides and labeled accordingly (Rajagopal, Kumar, \& Gowda, 1990). The samples were then moved to the laboratory where the multifaceted extractor (Berlese Tullgren Funnel) was adopted. Extraction methods were designed to suit behaviors and body structures of the organisms (Hopkin, 1997; Wallwork, 1970). The soil microarthropods were collected and put into containers with $70 \%$ alcohol within $48 \mathrm{~h}$ and examined under binocular microscope for proper identification. All experiments were replicated thrice.

To study the effect of insecticides on earthworm (Eisenia fetida L.), pot experiment with $2 \mathrm{~kg}$ organic matter (partially decomposed) was carried out. After imposing the treatments to the pot, ten earthworms will be inoculated in each treated pots and observation will be taken on the mortality and natality during $3,7,15$, and 30 days after treatment. The whole experiment was replicated in thrice.

The collected data is subjected to statistical analysis using Duncan's multiple range test (DMRT) to compare the specific difference of mean with the help of SPSS (21) software.

\section{Results and discussion}

\section{Arthropod abundance in soil under study}

Among the different arthropods present in the soil, we recorded the following classes of the phylum Arthropoda namely Insecta, Arachnida, Diplopoda, Chilopoda, Annelida, and Crustacea. Among the different classes present in the soil, class insecta accounts for $92.58 \%$ of the total population. The following other class comprises Arachnida (3.14\%), Diplopoda (1.3\%), Chilopoda (0.8\%), Annelida (1.62\%), and crustacean (0.50\%). Hymenoptera recorded the highest percentage of population (57.34\%) among the class Insecta followed by Isoptera, Collembola, Coleoptera, Orthoptera, Hemiptera, Dermaptera, Lepidoptera, and Dictyoptera. Under the order coleoptera; Carabidae, Staphylinidae, Scarabaeidae, Tenebrionidae, and Chrysomelidae were identified. Among the apterigotes, collembola was found as predominant arthropods which account for 9.42\% of the total Insecta class (Table 1). Folsomida candida under the family Poduridae is the predominant species under the order Collembola. Under the order Hemiptera, families like Pyrrhocoridae, Pentatomidae, and Cydnidae were found. Species diversity and species richness indices were calculated for insects associated and presented in Table 2.

This sample revealed a hitherto unsuspected abundance and diversity of insects associated with cucurbit fruits in Cameroon and highlighted the richness of insects found in rice maize-based agro-ecosystem. Many ecologists have found it useful to group insects into guilds to study the ecological interactions between insects, their hosts, their natural enemies, and climate (Speight, Hunter, \& Watt, 2008). Djiéto-Lordon and Aléné (2006) in their study reported that Diptera and Hymenoptera were numerically preponderant over other order. Santos and Cabanas (2007) reported that Formicidae catch is found dominant in pitfall traps in olive groves. Mites, mainly oribatids, were the also abundant. Oribatid mites have similar ecological functions as Collembola; they are agents of organic matter decomposition and consequently are important in nutrient recycling; usually feed on dead and dying tissues and/or yeasts, bacteria, and algae (Krantz, 1978), and are part of the diet of some ant species (Wilson, 2005). The predatory arthropod community was subjugated by Carabidae and Formicidae. Similar observations were concluded by Orsini, Daane, Sime, and Nelson (2007).

\section{Effect of insecticides on collembola}

The effect of test insecticides on one of the most important arthropods present in the soil for maintaining the soil fertility, i.e., Collembola, is depicted in Table 3. Collembola fauna obtained per $500 \mathrm{~g}$ of soil in different treatments prior to application of insecticides ranged from 0.88 to 1.50 numbers (nos.). After 15 days of the application of the insecticides, maximum collembolan population was found in Rynaxypyr treated plot (1.85 nos.) which was followed by fipronil, cartap hydrochloride, and chlorpyriphos. It is quite clear from the data recorded on 15 days, all the insecticidal treatments showed no negative effect on collembolan population compared to pretreatment. Carbofuran exerted neutral effect on the collembolan population (1.85 nos.) followed by fipronil, cartap hydrochloride, chlorpyriphos, and imidacloprid. During 30 days after application, same trend was followed. Rynaxypyr again recorded the highest collembolan population among the treatments followed by chlorpyriphos. Seventy-five days after, application shows that Fipronil recorded maximum collembolan population (1.93) for $500 \mathrm{~g}$ of soil. It is prominent from the table that there was no significant difference within the treatments during 30 days and 75 days after application of insecticide which may be denoted that there was no pesticidal effect 
Table 1 Abundance of soil arthropods found in the experimental location

\begin{tabular}{|c|c|c|c|c|}
\hline Class & Order & Family & Individuals & $\%$ over total count \\
\hline \multirow[t]{9}{*}{ Insecta } & Coleoptera & $\begin{array}{l}\text { Carabidae, Staphylinidae, Scarabaeidae, } \\
\text { Tenebrionidae, Chrysomelidae }\end{array}$ & 49 & $5.3 \%$ \\
\hline & Collembola & Poduridae & 86 & $9.42 \%$ \\
\hline & Orthoptera & $\begin{array}{l}\text { Gryllotalpidae, Gryllideae, Arctidae, } \\
\text { Tettigonidae }\end{array}$ & 26 & $2.85 \%$ \\
\hline & Hymenoptera & Formicidae & 523 & $57.34 \%$ \\
\hline & Isoptera & Termitidae & 183 & $20.06 \%$ \\
\hline & Dermaptera & Forficulidae & 16 & $1.75 \%$ \\
\hline & Hemiptera & $\begin{array}{l}\text { Pyrrhocoridae, Pentatomidae, } \\
\text { Cydnidae }\end{array}$ & 21 & $2.30 \%$ \\
\hline & Dictyoptera & Blattellidae & 3 & $0.32 \%$ \\
\hline & Lepidoptera & Noctuidae & 5 & $0.54 \%$ \\
\hline Total & & & 912 & $92.58 \%$ \\
\hline \multirow[t]{3}{*}{ Arachnida } & Oribatida & Trombiidae, Phthiracaridae & 31 & $3.14 \%$ \\
\hline & Araneae & & & \\
\hline & Pseudoscorpionida & & & \\
\hline Diplopoda & & & 13 & $1.3 \%$ \\
\hline Chilopoda & & & 8 & $0.8 \%$ \\
\hline Annelida & & & 16 & $1.62 \%$ \\
\hline Crustacea & Isopoda & Porcellionidae & 5 & $0.50 \%$ \\
\hline Total & & & 985 & \\
\hline
\end{tabular}

on the collembolan during 30 and 75 days after application. The mean data of collembolan population shows that the collembolan population ranged from 1.02 to 1.72 per $500 \mathrm{~g}$ of soil. Rynaxypyr recorded the highest collembolan population (1.72 nos.) while the control plot recorded 1.41 numbers of individuals. Then, a $21.98 \%$ increased population was noted in rynaxypyr-treated plot. All the insecticides except carbofuran and phorate recorded more population than of control. From our above experimental result, we can conclude that insecticides under test exerted no negative effect on collembola. Our experimental result is comparable with the findings of Karam (2011) who also reported that rynaxypyr, cartap hydrochloride, fipronil, and carbofuran have no significant effect on the arthropods present in soil at the end of the crop season. The effect of insecticides on soil arthropods as reported by different workers worldwide is quite ambiguous. Fountain and

Table 2 Species diversity and species richness indices calculated for insects associated

\begin{tabular}{ll}
\hline Indices & Value \\
\hline Shanon_H' & 1.60 \\
Pielo's evenness & 0.61 \\
Simpson_1-D & 0.68 \\
Berger Parker_d & 1.88 \\
Margalef_DMg & 1.89 \\
\hline
\end{tabular}

Hopkin (2004) reported that the total number of collembolan increased tenfold despite the abundance of spider species being reduced when chlorpyriphos was sprayed on field. According to Komal, Singh, and Sharma (2006), acari were the most sensitive arthropods to insecticides than collembolan. He also reported that no noticeable change in collembolan population was observed after the insecticidal application. Michereff, Guedes, Della-Lucia, Michereff, and Cruz (2004) reported that chlorpyriphos have no negative effect on collembolan and acari present in the soil. Our experimental result shows that carbofuran and phorate recorded less population in respect of control but the successive data recorded at different intervals shows retarded growth of reproduction but no inhibitory trend was noticed; this reports contradicts with the findings of Singh and Gupta (1994) who concluded that phorate was toxic to soil arthropods while collembolan being the most sensitive.

\section{Effect of insecticides on minute arthropods}

Several minute soil arthropods like minute ants, beetles, soil oribatid mites, and pseudoscorpions perform several bio-ecological functions in recycling of several organic waste and toxicants in maintaining the soil ecosystem. It was found that the population of minute arthropod abundance as a whole obtained per $500 \mathrm{~g}$ of soil in different treatments prior to application of insecticides was ranged from 0.88 to 1.55 nos. and there was no statistical 
Table 3 Effect of insecticides on collembolan population (per $500 \mathrm{~g}$ of soil) at different intervals

\begin{tabular}{|c|c|c|c|c|c|c|}
\hline Treatment & Pre treatment & 15days & 30 days & 75 days & Mean & $\begin{array}{l}\% \text { reduction/increase } \\
\text { over control }\end{array}$ \\
\hline$\overline{\mathrm{T}_{1}{ }^{*}}$ & $1.4 \pm 0.12^{\mathrm{ab}^{* *}}$ & $1.85 \pm 0.27^{a}$ & $1.94 \pm 0.31^{\mathrm{a}}$ & $1.71 \pm 0.57^{\mathrm{a}}$ & 1.72 & +21.98 \\
\hline $\mathrm{T}_{2}$ & $1.5 \pm 0.32^{\mathrm{ab}}$ & $1.76 \pm 0.31^{a}$ & $1.67 \pm 0.39^{a}$ & $1.93 \pm 0.38^{\mathrm{a}}$ & 1.71 & +21.27 \\
\hline$T_{3}$ & $1.34 \pm 0.20^{\mathrm{ab}}$ & $1.46 \pm 0.20^{\mathrm{ab}}$ & $1.67 \pm 0.16^{\mathrm{a}}$ & $1.67 \pm 0.16^{\mathrm{a}}$ & 1.53 & +8.51 \\
\hline $\mathrm{T}_{4}$ & $0.88 \pm 0.29^{b}$ & $0.88 \pm 0.29^{b}$ & $1.17 \pm 0.43^{\mathrm{a}}$ & $1.17 \pm 0.43^{\mathrm{a}}$ & 1.02 & -27.65 \\
\hline$T_{5}$ & $1.05 \pm 0.29^{\mathrm{ab}}$ & $1.29 \pm 0.50^{\mathrm{ab}}$ & $1.18 \pm 0.81^{\mathrm{a}}$ & $1.38 \pm 0.60^{\mathrm{a}}$ & 1.22 & -13.47 \\
\hline $\mathrm{T}_{6}$ & $1.35 \pm 0.71^{\mathrm{ab}}$ & $1.38 \pm 0.60^{\mathrm{ab}}$ & $1.64 \pm 0.26^{\mathrm{a}}$ & $1.77 \pm 0.16^{\mathrm{a}}$ & 1.53 & +8.51 \\
\hline $\mathrm{T}_{7}$ & $1.17 \pm 0.43^{\mathrm{ab}}$ & $1.43 \pm 0.37^{\mathrm{ab}}$ & $1.77 \pm 0.16^{\mathrm{a}}$ & $1.76 \pm 0.31^{\mathrm{a}}$ & 1.53 & +8.51 \\
\hline $\mathrm{T}_{8}$ & $1.26 \pm 0.58^{\mathrm{ab}}$ & $1.29 \pm 0.50^{\mathrm{ab}}$ & $1.56 \pm 0.75^{a}$ & $1.56 \pm 0.75^{a}$ & 1.41 & - \\
\hline
\end{tabular}

${ }^{*} T_{1}=$ Rynaxypyr, $T_{2}=$ Fipronil, $T_{3}=$ Cartap hydrochloride, $T_{4}=$ Carbofuran, $T_{5}=$ Phorate, $T_{6}=$ Imidacloprid, $T_{7}=$ Chlorpyrifos, $T_{8}=$ Control

**Numbers followed by same letters are statistically at par (otherwise significantly different at $p<0.05$ )

difference between any of the treatments. After 15 days of the application of the insecticides, maximum abundance of minute arthropods was recorded in rynaxypyr-treated plot (1.55 nos.) which was followed by fironil, phorate, and imidacloprid. During 30 days after application of insecticides, same trend was followed. Rynaxypyr again recorded the highest population among the treatments. The data recorded on 30 days after application of insecticides shows that rynaxypyr-treated plot recorded maximum minute arthropod abundance (1.77 nos.) (Table 4). It is prominent from the table that there was no significant difference within the treatments during observation taken on 7 and 15 days after application of insecticides, whereas significant difference was noticed on 30 days after application of insecticide. Rynaxypyr showed significant difference in minute arthropods population count (other than collembolan) over carbofuran, phorate, and control plots. The mean data of minute arthropod population ranged from 0.91 to 1.43 nos. per $500 \mathrm{~g}$ of soil. Rynaxypyr recorded the maximum population of minute arthropods while the control plot recorded 0.71 nos. of minute arthropods. It is quite prominent from the data that all the treatments exerted no appreciable toxic effect rather pronounced increased level of population was recorded over control. Interaction of insecticides on the soil-borne fungi is negative as reported by several researchers, and it may be collaborated that reduction of entomopathogenic fungi (Verticillium, Beauveria, Metarrhizium) in the treated plot may lead to increase of population of minute arthropods. Michereff et al. (2004) suggested that the impact of chlorpyriphos on soil arthropods was less severe than expected. Woreta (1999a, 1999b) also reported carbofuran did not significantly diminish the number of carabids. According to Karam (2011), the effect of insecticides on macro- and microarthropods like minute ants, beetles, and soil oribatid mites was nonsignificant.

\section{Effect of insecticides on earthcasts}

Earthworm is the most important arthropod for maintaining the soil health. It is important to assay the impact of insecticides (soil applicated) on the earthworm present in soil. Earthcast is an indicator of the presence of earthworm in the soil; therefore, the impact analysis of the insecticides on earthworm was evaluated upon the earthcast and duly presented in Table 5. The count of earthcast was varied from 0.88 to 1.17 nos. prior to application of insecticides. After 15 days of the application of the insecticides, maximum abundance of earthcasts was found in carbofuran-

Table 4 Effect of insecticides on minute arthropods in soil at different intervals

\begin{tabular}{|c|c|c|c|c|c|c|}
\hline Treatment & Pre treatment & 7 days & 15 days & 30 days & Mean & $\begin{array}{l}\% \text { reduction / increase } \\
\text { over control }\end{array}$ \\
\hline$\overline{\mathrm{T}_{1}{ }^{*}}$ & $1.55 \pm 0.32^{\mathrm{a}^{* *}}$ & $1.46 \pm 0.20^{\mathrm{a}}$ & $1.55 \pm 0.32^{\mathrm{a}}$ & $1.77 \pm 0.09^{\mathrm{a}}$ & 1.43 & +57.14 \\
\hline $\mathrm{T}_{2}$ & $1.17 \pm 0.43^{a}$ & $1.29 \pm 0.50^{\mathrm{a}}$ & $1.43 \pm 0.37^{\mathrm{a}}$ & $1.09 \pm 0.38^{\mathrm{ab}}$ & 1.24 & +36.26 \\
\hline$T_{3}$ & $0.88 \pm 0.29^{a}$ & $1.05 \pm 0.29^{a}$ & $1.17 \pm 0.43^{\mathrm{a}}$ & $1.00 \pm 0.29^{\mathrm{ab}}$ & 1.02 & +12.08 \\
\hline $\mathrm{T}_{4}$ & $0.88 \pm 0.29^{a}$ & $1.05 \pm 0.29^{a}$ & $1.29 \pm 0.50^{\mathrm{a}}$ & $0.88 \pm 0.17^{b}$ & 1.02 & +12.08 \\
\hline $\mathrm{T}_{5}$ & $1.17 \pm 0.43^{\mathrm{a}}$ & $1.29 \pm 0.50^{\mathrm{a}}$ & $0.88 \pm 0.29^{a}$ & $0.71 \pm 0.00^{b}$ & 1.01 & +10.98 \\
\hline $\mathrm{T}_{6}$ & $1.00 \pm 0.50^{\mathrm{a}}$ & $1.26 \pm 0.58^{\mathrm{a}}$ & $1.34 \pm 0.20^{\mathrm{a}}$ & $1.26 \pm 0.33^{\mathrm{ab}}$ & 1.21 & +32.96 \\
\hline $\mathrm{T}_{7}$ & $0.88 \pm 0.29^{a}$ & $1.00 \pm 0.50^{\mathrm{a}}$ & $1.17 \pm 0.43^{\mathrm{a}}$ & $1.05 \pm 0.17^{\mathrm{ab}}$ & 1.02 & +12.08 \\
\hline $\mathrm{T}_{8}$ & $1.05 \pm 0.29^{a}$ & $1.00 \pm 0.50^{\mathrm{a}}$ & $0.88 \pm 0.29^{a}$ & $0.71 \pm 0.00^{b}$ & 0.91 & \\
\hline
\end{tabular}

${ }^{*} \mathrm{~T}_{1}=$ Rynaxypyr, $\mathrm{T}_{2}=$ Fipronil, $\mathrm{T}_{3}=$ Cartap hydrochloride, $\mathrm{T}_{4}=$ Carbofuran, $\mathrm{T}_{5}=$ Phorate, $\mathrm{T}_{6}=$ Imidacloprid, $\mathrm{T}_{7}=$ Chlorpyrifos, $\mathrm{T}_{8}=$ Control

**Numbers followed by same letters are statistically at par (otherwise significantly different at $p<0.05$ ) 
Table 5 Effect of insecticides on earthcast (per $0.5 \mathrm{~m}^{2}$ area in field) at different intervals

\begin{tabular}{|c|c|c|c|c|c|c|}
\hline Treatment & Pre treatment & 15 days & 30days & 75 days & Mean & $\begin{array}{l}\text { \% reduction/ increase } \\
\text { over control }\end{array}$ \\
\hline$\overline{\mathrm{T}_{1}{ }^{*}}$ & $1.05 \pm 0.17^{\mathrm{a} *}$ & $1.05 \pm 0.17^{\mathrm{a}}$ & $1.17 \pm 0.25^{\mathrm{ab}}$ & $1.26 \pm 0.33^{\mathrm{ab}}$ & 1.13 & +3.66 \\
\hline $\mathrm{T}_{2}$ & $0.88 \pm 0.17^{\mathrm{a}}$ & $1.00 \pm 0.29^{a}$ & $1.17 \pm 0.25^{\mathrm{ab}}$ & $1.26 \pm 0.33^{\mathrm{ab}}$ & 1.07 & -1.83 \\
\hline $\mathrm{T}_{3}$ & $0.88 \pm 0.17^{a}$ & $1.00 \pm 0.29^{a}$ & $1.22 \pm 0.00^{\mathrm{ab}}$ & $1.38 \pm 0.34^{\mathrm{ab}}$ & 1.12 & +2.75 \\
\hline $\mathrm{T}_{4}$ & $0.88 \pm 0.17^{\mathrm{a}}$ & $1.34 \pm 0.12^{\mathrm{a}}$ & $1.29 \pm 0.29^{\mathrm{ab}}$ & $1.55 \pm 0.18^{a}$ & 1.26 & +15.59 \\
\hline$T_{5}$ & $0.88 \pm 0.17^{\mathrm{a}}$ & $0.88 \pm 0.17^{a}$ & $1.05 \pm 0.17^{\mathrm{ab}}$ & $1.17 \pm 0.25^{\mathrm{ab}}$ & 0.99 & -9.17 \\
\hline $\mathrm{T}_{6}$ & $1.17 \pm 0.25^{\mathrm{a}}$ & $1.00 \pm 0.29^{a}$ & $0.71 \pm 0.00^{\mathrm{a}}$ & $0.71 \pm 0.00^{b}$ & 0.89 & -18.34 \\
\hline $\mathrm{T}_{7}$ & $1.17 \pm 0.25^{a}$ & $1.05 \pm 0.17^{a}$ & $0.88 \pm 0.17^{b}$ & $0.71 \pm 0.00^{b}$ & 0.95 & -12.84 \\
\hline $\mathrm{T}_{8}$ & $0.88 \pm 0.17^{\mathrm{a}}$ & $1.00 \pm 0.29^{a}$ & $1.05 \pm 0.17^{\mathrm{ab}}$ & $1.46 \pm 0.12 \mathrm{ab}$ & 1.09 & - \\
\hline
\end{tabular}

${ }^{*} T_{1}=$ Rynaxypyr, $T_{2}=$ Fipronil, $T_{3}=$ Cartap hydrochloride, $T_{4}=$ Carbofuran, $T_{5}=$ Phorate, $T_{6}=$ Imidacloprid, $T_{7}=$ Chlorpyrifos, $T_{8}=$ Control

**Numbers followed by same letters are statistically at par (otherwise significantly different at $p<0.05$ )

treated plot (1.34 nos.) which is followed by rynaxypyr and chlorpyrifos (1.05 nos.). Significant variation was noticed on 30 days and successive days on observation. During 30 days after application of insecticides, imidacloprid, carbofuran, and chlorpyrifos exerted negative impact on the earthcast count. Lowest count was obtained by imidacloprid $(0.71$ nos.). The data recorded on 75 days after application of insecticides shows that carbofuran-treated plot recorded maximum abundance ( 1.55 per $0.5 \mathrm{~m}^{2}$ area). Imidacloprid and chlorpyrifos both recorded the lowest count (0.71 nos.). The mean count of earthcast abundance was ranged from 0.89 to 1.26 per $0.5 \mathrm{~m}^{2}$ area. Carbofuran recorded the highest population of earthcasts while the control plot recorded 1.09 nos. It was noticed that insecticides under question showed mixed effect on the earthworm population (reflected through earchcast) as imidacloprid, chlorpyrifos, and phorate showed negative impact, while the rest of the insecticides resulted positive impact over untreated check. Maximum growth and multiplication was noticed in carbofuran-treated plot (15.59\%). Our findings can be explained along with the findings of Karam (2011), who reported that the abundance of earthcast did not vary significantly from untreated control which is also prominent from the results of the present study. During the present investigation, Carbofuran was found to have the most positive impact on earthcast abundance which is comparable with the findings of Karam (2011) who reported that rynaxypyr, carbofuran, and cartap hydrochloride did not significantly reduced the population of soil fauna. As most of the insecticides selected to evaluate the effect of insecticides on soil arthropods are novel and target-specific toward target pests, thus wielded less toxicity toward other non-target organisms.

\section{Effect of insecticides on earthworm (Eisenia fetida L)}

The present author underwent the studies on the selected insecticides effect on the common vermicomposting agent, i.e., the Red Earthworm (Eisenia fetida. L.), to evaluate the direct impact of the test insecticides on earthworm, which is depicted in Table 6 . It is very much lucid to interpret that the earthworm population remained unaffected up to 7 days after inoculation. Thus all the treatments were statistically at par on 3 and 7 days after inoculation. During 15 days after inoculation, the effect of insecticides on earthworm population was pronounced. It was recorded that rynaxypyr, fipronil, and carbofuran influenced the earthworm population; rynaxypyr and

Table 6 Effect of insecticides on Earthworm (Eisenia fetida L.) at different intervals

\begin{tabular}{|c|c|c|c|c|c|c|c|c|c|}
\hline Treatment & Pre treatment & 3Days & 7Days & 15Days & $\begin{array}{l}\text { \% reduction/ increase } \\
\text { over control }\end{array}$ & 30Days & $\begin{array}{l}\text { \% reduction/ increase } \\
\text { over control }\end{array}$ & Mean & $\begin{array}{l}\text { \% reduction/ increase } \\
\text { over control }\end{array}$ \\
\hline$\overline{\mathrm{T}_{1}{ }^{*}}$ & 15.00 & 15.00 & 15.00 & $15.66 \pm 0.66^{a}$ & +4.4 & $32 \pm 1.52^{a^{* *}}$ & +9.10 & 18.50 & +3.93 \\
\hline $\mathrm{T}_{2}$ & 15.00 & 15.00 & 15.00 & $15.33 \pm 0.33^{\mathrm{a}}$ & +2.2 & $31.6 \pm 2.40^{\mathrm{a}}$ & +7.73 & 18.30 & +2.80 \\
\hline$T_{3}$ & 15.00 & 15.00 & 15.00 & $14.66 \pm 0.33^{\mathrm{ab}}$ & -2.26 & $24.33 \pm 1.85^{b c}$ & -17.04 & 16.70 & -6.17 \\
\hline $\mathrm{T}_{4}$ & 15.00 & 15.00 & 15.00 & $15.66 \pm 0.88^{\mathrm{a}}$ & +4.4 & $21.66 \pm 2.72^{c}$ & -26.15 & 16.40 & -7.86 \\
\hline $\mathrm{T}_{5}$ & 15.00 & 15.00 & 15.00 & $14.66 \pm 0.33^{\mathrm{ab}}$ & -2.26 & $21.33 \pm 2.90^{c}$ & -27.27 & 16.19 & -9.04 \\
\hline $\mathrm{T}_{6}$ & 15.00 & 15.00 & 15.00 & $10.33 \pm 1.45^{c}$ & -31.13 & $4.33 \pm 1.85^{d}$ & -85.23 & 11.90 & -33.14 \\
\hline $\mathrm{T}_{7}$ & 15.00 & 15.00 & 15.00 & $13 \pm 0.57^{b}$ & -13.33 & $10 \pm 1.15^{d}$ & -65.90 & 13.10 & -26.40 \\
\hline $\mathrm{T}_{8}$ & 15.00 & 15.00 & 15.00 & $15 \pm 0.0^{\mathrm{ab}}$ & - & $29.33 \pm 1.85^{\mathrm{ab}}$ & - & 17.80 & - \\
\hline
\end{tabular}

${ }^{*} T_{1}=$ Rynaxypyr, $T_{2}=$ Fipronil, $T_{3}=$ Cartap hydrochloride, $T_{4}=$ Carbofuran, $T_{5}=$ Phorate, $T_{6}=$ Imidacloprid, $T_{7}=$ Chlorpyrifos, $T_{8}=$ Control

**Numbers followed by same letters are statistically at par (otherwise significantly different at $p<0.05$ ) 
carbofuran recorded 15.66 number of earthworms on 15 days after application of insecticides which is followed by Fipronil (15.33 individuals per pot). Imidacloprid was recorded as the most deleterious insecticide (10.33 individuals per pot) against Eisenia fetida L., which was followed by chlorpyriphos (13.00 nos.), cartap hydrochloride, and phorate (14.66 individuals per plot both). The data recorded on 30 days after application of insecticides showed all the treatments except imidacloprid and chlorpyriphos influenced the population of Eisenia fetida L. Rynaxypyr again recorded the highest number of individuals ( 32.00 individuals per pot). It is prominent from the data recorded on 30 days after application of insecticides that imidacloprid exerted very much detrimental effect on the earthworm population (4.33 individuals per pot) which is followed by chlorpyriphos (10.00). In the control pot, 29.33 individuals were recorded on the final date of observation. The highest mean number of earthworm population was recorded by rynaxypyr (18.5 nos.) followed by fipronil (31.66 nos.), while in control pot, 17.8 individuals were recorded. Imidacloprid was found as the most toxic toward redworm (33.14\% reduction of population over untreated check) followed by chlorpyrifos.

From the above result discussed earlier, it is unambiguous to say that the standard test earthworm species was sensitive toward imidacloprid and chlorpyriphos, while less sensitive to rynaxypyr, fipronil, carbofuran, phorate, and cartap hydrochloride. The growth and reproduction of the worms was not hindered by rynaxypyr, fipronil, carbofuran, and cartap hydrochloride. Frampton et al. (2006) reported that earthworm species Eisenia fetida L. is less sensitive to insecticides which is in line with the findings of the present author. Alshawish, Mohamed, and Nair (2004) concluded that chlorpyriphos was toxic to earthworm mortality which is comparable to the findings of the present author. Studies show that imidacloprid had potentially harmful effect on Eisenia fetida L. (Chen et al., 2014; Zhang, Zhang, \& Wang, 2014). Tu et al. (2011) reported that imidacloprid significantly inhibited earthworm feeding activity. According to Karam (2011), rynaxypyr did not affect the earthworm population negatively which is similar to our present results. Most of the test insecticides selected (rynaxypyr, fipronil, carbofuran) influenced earthworm biology except imidacloprid and chlorpyriphos which is also evident from the previous records and studies by various authors.

\section{Conclusion}

It is pertinent from the experimental result that the richness of 6 arthropod classes was recognized from the experimental site documented with 13 different orders. Insecta documented maximum richness. The insecticides except imidacloprid and phorate documented no harmful toxic effect on the collembola population, whereas minute arthropods except collembola showed less sensitivity toward the insecticides. Imidacloprid showed toxic effects toward the earthworm population. In the case of chlorpyrifos, the wild population of earthworm showed reduced toxicity than that of E. fetida.

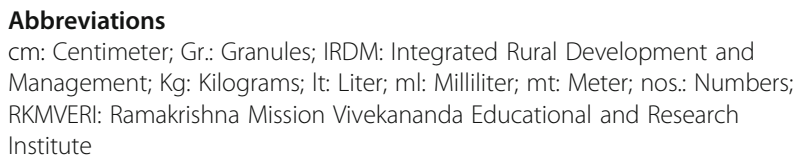

\section{Acknowledgements}

We would like to thank Sasya Shyamala Farm Science Centre, Ramakrishna Mission Vivekananda Educational and Research Institute for providing necessary facilities.

\section{Funding}

Not applicable.

\section{Availability of data and materials}

All database required authors approval upon request.

\section{Authors' contributions}

AG formulated the research. AH conducted the sampling and trial under the guidance of first author. First author prepared the manuscript. Both of the authors read and approved the manuscript.

Ethics approval and consent to participate Not applicable.

Consent for publication

Not applicable.

\section{Competing interests}

The authors declare that they have no competing interests.

\section{Publisher's Note}

Springer Nature remains neutral with regard to jurisdictional claims in published maps and institutional affiliations.

\section{Author details}

'Sasya Shyamala Farm Science Centre, Ramakrishna Mission Vivekananda Educational and Research Institute (RKMVERI), Sonarpur, Kolkata, West Bengal 700150, India. ${ }^{2}$ Integrated Rural Development and Management Faculty Centre (IRDM), RKMVERI, Narendrapur, Kolkata, West Bengal 700103, India.

Received: 18 August 2018 Accepted: 6 January 2019

Published online: 01 February 2019

\section{References}

Adamski, Z., Błoszyk, J., Bruin, J., \& Ziemnicki, K. (2007). Non-omniamorianturtoxicity of mancozeb on dead wood microarthropod fauna. Experimental and Applied Acarology, 42, 47-53.

Al-Assiuty, A. I. M., Bayoumi, B. M., Khalil, M. A., \& Van Straalen, N. M. (1993). Egg number and abundance of ten Egyptian oribatid mite species (Acari: Cryptostigmata) in relation to habitat quality. European Journal of Soil Biology, 29, 59-65.

Allwood, A. J. (1996). Biology and ecology: prerequisites for understanding and managing fruit flies (Diptera: Tephritidae), pp. 95-101. Allwood, A. J. and Drew, R.A.I. (Eds.), Management of fruit flies in the Pacific. A regional symposium, ACIAR, Canberra. Nadi, Fiji.

Alshawish, S. A., Mohamed, A. I., \& Nair, G. A. (2004). Prolonged toxicity of sublethal dosages of chemical pesticides on the body mass and cocoons of Aporrectodea caliginosa (Savigny 1826) (Oligochaeta: Lumbricidae) inhabiting Benghazi, Libya. Proceedings of National Academy of Science, Section B, Biological Sciences, Publisher Spinger, India, 74, 123-133.

Bhuyan, S., Sreedharan, B., Adhya, T. K., \& Sethunathan, N. (1993). Enhanced biodegradation of $\mathrm{g}$-hexachlorocyclohexane ( $\mathrm{g}-\mathrm{HCH}$ ) in $\mathrm{HCH}$ (commerial) acclimatized flooded soil: factors affecting its development and persistence. Pesticide Science, 38, 49-55, 
Blasco, C., \& Pico, Y. (2009). Prospects for combining chemical and biological methods for integrated environmental assessment. TrAC Trends in Analytical Chemistry, 28, 745-757.

Butcher, J., Snider, W. R., \& Snider, R. J. (1971). Bioecology of edaphic Collembola and Acarina. Annual Review of Entomology, 16, 249-288.

Charmillot, P. J., Pasquier, D., Zufferey, E., \& Bovard, A. (2001). Trial to control grape moth by mating disruption in Denzaley vineyard in 1999 and 2000 Revue Suisse De Viticulture, Arboril. et Horticulture, 33, 247-251.

Chen, C., Wang, Y., Zhao, X., Wang, Q., \& Qian, Y. (2014). Comparative and combined acute toxicity of butachlor, imidacloprid and chlorpyriphos on earthworm, Eisenia fetida. Chemosphere, 100, 111-115.

Colwell, R. K., \& Coddington, J. A. (1994). Estimating terrestrial biodiversity through extrapolation. Philosophical Transactions of the Royal Society B, 345, 101-118.

Cortet, J., Poinsot-Balaguer, N., Gillon, D., Joffre, R., \& Ourcival, J. M. (2002). Effects of pesticides on microarthropods and organic matter recycling in a maize field: use and discussion of the litter-bag methodology. European Journal of Soil Biology, 38, 261-265.

Cortet, J., Vauflery, A. G. D., Balaguer, N. P., Gomot, L., Texier, C., \& Cluzeau, D. (1999). The use of invertebrate soil fauna in monitoring pollutant effects. European Journal of Soil Biology, 35, 115-134.

Das, A. C., \& Mukherjee, D. (2000). Influence of insecticides on microbial transformation of nitrogen and phosphorus in Typic Ochraqualf soil. Journal of Agricultural and Food Chemistry, 48, 3728-3732.

Djiéto-Lordon, C., \& Aléné, D. C. (2006). Inventaire diagnostique des insectes de quelques cultures dans les exploitations maraîchéres périurbaines dans la région de Yaoundé, Cameroun. In F. Bella Manga, A. Kamga, D. Omokolo, \& M. Havard (Eds.), Actesatelier de présentation des opérations de recherche participative, (pp. 7-18). Yaoundé: Pôle de Compétence en Partenariat (PCP) Grand Sud Cameroun.

El-Shahaat, M. S., Othman, M. A. S., El-Halfawy, M., \& Marei, A. S. (1987). Effect of carbamate and synthetic pyrethroid pesticides of some soil microbial activities. Alexandria Journal of Agricultural Research, 32, 427-438.

Fountain, M. T., \& Hopkin, S. P. (2004). A comparative study of the effects of metal contamination on Collembola in the field and in the laboratory. Ecotoxicology, 13, 573-587

Frampton, G. K., Stephan, J., Scott-Fordsmand, J., Rombke, J. \& Van den Brink, P. J. (2006). Effects of pesticides on soil invertebrates in laboratory studies: a review and analysis using species sensitivity distributions. Environmental Toxicology and Chemistry, 25, 2480-2489.

Ghosal, A., Hati, A., Mal, S., Mukherjee, A., \& Mukherjee, A. (2018). Impact of some new generation insecticides on beneficial rhizospheric microorganisms in rice maize cropping system. International Journal of Current Microbiology and Applied Sciences, 7, 666-676.

Goncalves, M. F., \& Pereira, J. A. (2012). Abundance and diversity of soil arthropods in the olive grove ecosystem. Journal of Insect Science, 12, 20.

Gotelli, N. J. (2004). A taxonomic wish-list for community ecology. Philosophical Transactions of the Royal Society B, 359, 585-597.

Hopkin, S. P. (1997). Biology of the springtails (Insecta: Collembola), (p. 234). New York: Oxford University Press.

Karam, N. (2011). Investigations on the bioefficacy of a ryanodine receptor agonist in controlling two lepidopteran borer pests and its impact on non target organisms, Ph.D. dissertation (). West Bengal: Department of Agricultural Entomology, Bidhan Chandra Krishi Viswa-vidyalaya.

Komal, V., Singh, D. K., \& Sharma, P. K. (2006). Endosulfan and quinalphos residues and toxicity microarthropods after repeated applications in field investigation. Journal of Environmental Science and Health, 41, 681-692.

Krantz, G. W. (1978). A Manual of Acarology, (2nd ed., ). (Oregon State University Book Stores, Inc., Corvallis, Oregon) Second Printing (emended 1986): [i]-vii, [1]-509.

Magurran, A. E. (2004). Measuring biological diversity. Malden: Blackwell.

McGill, B. J., Etienne, R. S., Gray, J. S., Alonso, D., Anderson, M. J., Benecha, H. K., ... He, F. (2007). Species abundance distributions: moving beyond single prediction theories to integration within an ecological framework. Ecology Letters, 10, 995-1015.

Melbourne, B. A. (1999). Bias in the effect of habitat structure on pitfall traps: an experimental evaluation. Australian Journal of Ecology, 24, 228-239.

Michereff, M., Guedes, R. N. C., Della-Lucia, T. M. C., Michereff, M. F. F., \& Cruz, I. (2004). Non-target impact of chlorpyrifos on soil arthropods associated with notillage cornfields in Brazil. International Journal of Pest Management, 50, 91-99.

Orsini, M. M., Daane, K. M., Sime, K. R., \& Nelson, E. H. (2007). Mortality of olive fruit fly pupae in California. Biocontrol Science and Technology, 17, 797-807.
Petersen, H. (2002). General aspects of collembolan ecology at the turn of the millennium. Pedobiologia, 46, 246-260.

Peterson, H., \& Luxton, M. (1982). A comparative analysis of fauna population and their role in decomposition processes. Oikos, 39, 287-388.

Rache, K. D., \& Coats, J. (1988). Comparative biodegradation of organophosphorus insecticides in soil. Specificity of enhanced microbial biodegradation. Journal of Agricultural and Food Chemistry, 36, 193-199.

Rajagopal, D., Kumar, P., \& Gowda, G. (1990). Effect of newer granular insecticides on soil fauna in groundnut cropping system. Journal of Soil Biology \& Ecology, 10, 36-40.

Santos, S. A. P., \& Cabanas, J. E. (2007). Pereira abundance and diversity of soil arthropods in olive grove ecosystem (Portugal): Effect of pitfall trap type. European Journal of Soil Biology, 43, 77-83.

Sarao, P. S., \& Kaur, H. (2014). Efficacy of Ferterra 0.4\% GR (chlorantraniliprole) against stem borers and leaf folder insect-pests of basmati rice. Journal of Environmental Biology, 35, 815-819.

Singh, R. and Gupta, G. P. (1994). Bioefficacy of systemic insecticides against target pest jassid and their impact on non target soil microarthropds in cotton (Gossypium spp.). Indian Journal of Entomology, 56, 313-321.

Speight, M. R., Hunter, M. D., \& Watt, A. D. (2008). Ecology of insects: concepts and applications, (2nd ed., ). Singapore: Wiley-Blackwell.

Tu, C., Wang, Y., Duan, W., Hertl, P., Tradway, L., Brandenburg, R., ... Hu, S. (2011). Effects of fungicides and insecticides on feeding behavior and community dynamics of earthworms: Implications for casting control in turfgrass systems. Applied Soil Ecology, 47, 31-36.

Wallwork, J. A. (1970). Ecology of soil animals, (p. 280). London: McGraw Hill Publisher.

Wilson, E. O. (2005). Oribatid mite predation by small ants of the genus Pheidole. Insectes Sociaux, 52, 263-265.

Woreta, D. (1999a). Biological activity of insecticides used to control Melolontha spp. adults (in Polish with English summary). Prace IBL, 869, 61-74.

Woreta, D. (1999b). The impact of systemic soil insecticides on epigeic Carabidae assemblages. Prace Instytutu Badawczego Lesnictwa, Seria A, 878/883, 5-22.

Zhang, Q., Zhang, B., \& Wang, C. (2014). Eco-toxicological effects on the earthworm, Eisenia fetida following exposure to soil contaminated with imidacloprid. Environmental Science and Pollution Research, 21, 12345-12353.

\section{Submit your manuscript to a SpringerOpen ${ }^{\circ}$ journal and benefit from:}

- Convenient online submission

- Rigorous peer review

- Open access: articles freely available online

High visibility within the field

- Retaining the copyright to your article

Submit your next manuscript at $>$ springeropen.com 